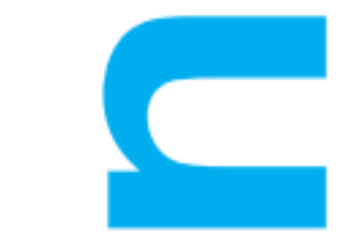

है
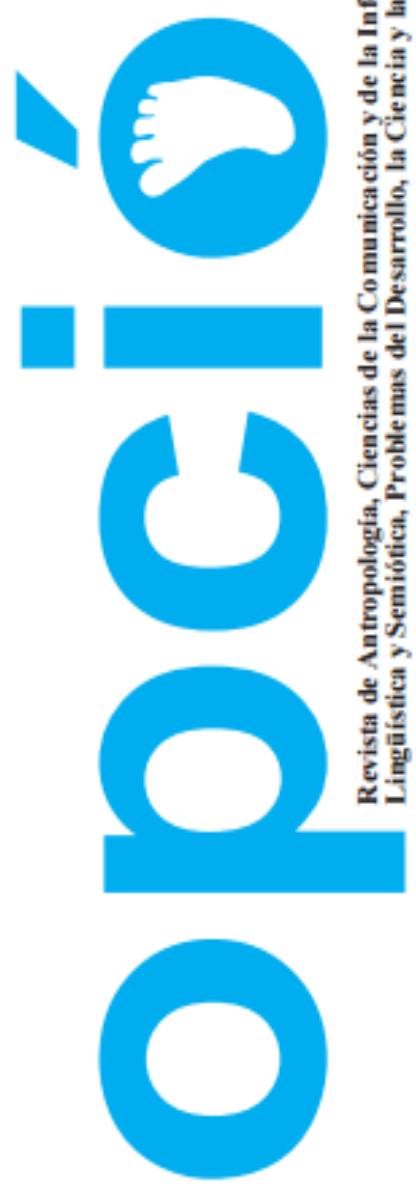

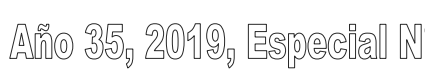

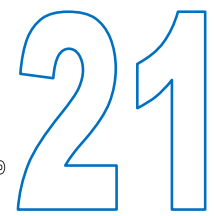

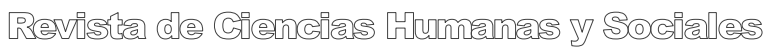

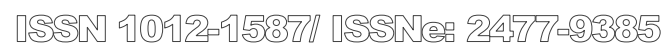

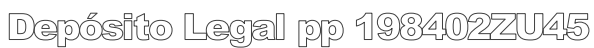

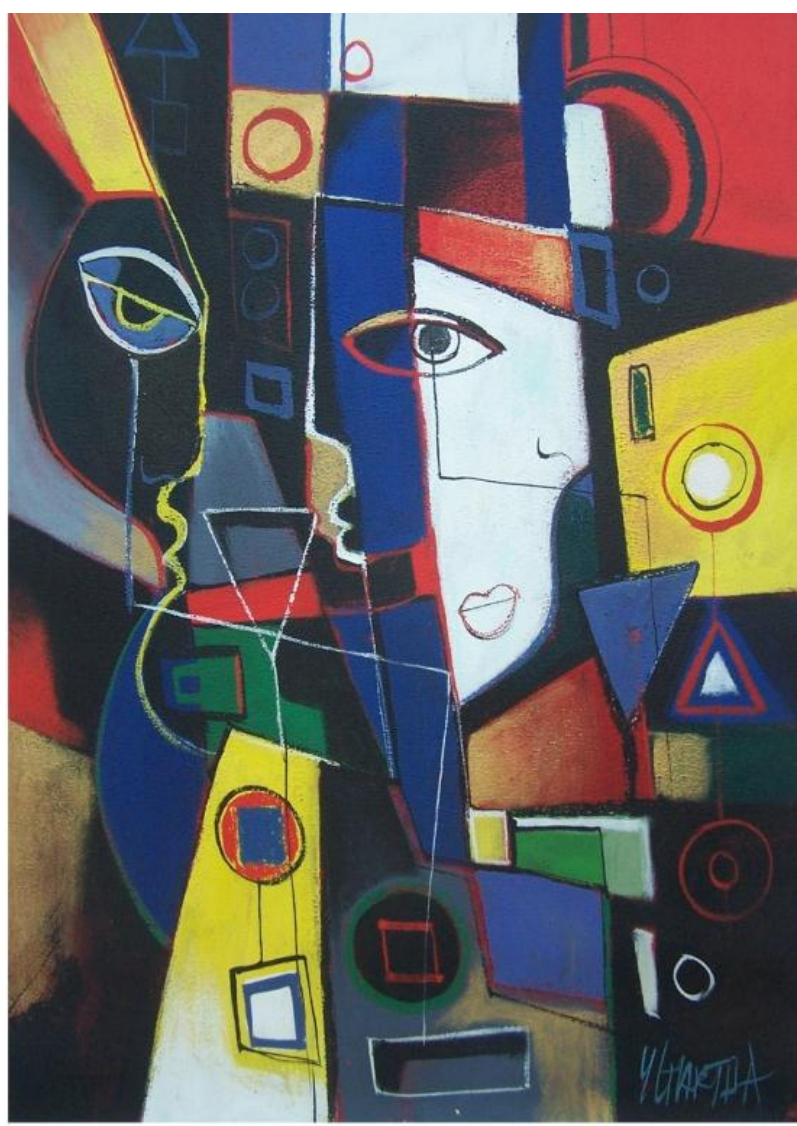

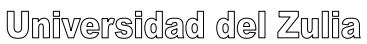

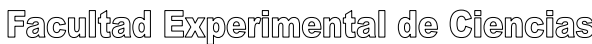

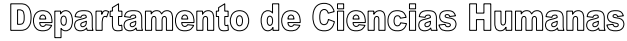

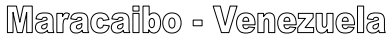





\title{
An analysis of brass casting parameter process using sand casting mold
}

\author{
M. Nasrul Kamal \\ Universitas Negeri Padang, West Sumatera, Indonesia \\ kamal93@fbs.unp.ac.id
}

\begin{abstract}
This research tried to analyze the existing casting process of ganto recycled brass by varying the liquid pressure parameters of different induction metals, followed by the pouring of liquid metal into the mold. The method used in this research was descriptive qualitative with aesthetic analysis. As a result, metal casting can be defined as the process of molten metal, poured into a mold, then allowed to be cool and freeze. In conclusion, Ganto is one of the objects of brass casting that continues to produce the brass handicrafts in Jorong Kapalo Koto, especially the production center of Zikri ganto.
\end{abstract}

Keywords: Sand, casting, ganto brass, handicraft.

\section{Un análisis del proceso de parámetros de fundición de latón utilizando molde de arena}

\section{Resumen}

Esta investigación trató de analizar el proceso de fundición existente del latón reciclado con ganto mediante la variación de los parámetros de presión del líquido de diferentes metales de inducción, seguido del vertido de metal líquido en el molde. El método utilizado en esta investigación fue descriptivo cualitativo con análisis estético. Como resultado, la fundición de metal se puede definir como el proceso de metal fundido, se vierte en un molde y luego se deja enfriar y congelar. En conclusión, Ganto es uno de los objetos de fundición de latón que continúa produciendo las artesanías de latón en Jorong Kapalo Koto, especialmente el centro de producción de Zikri Ganto. 
Palabras clave: arena, fundición, latón ganto, artesanía.

\section{INTRODUCTION}

West Sumatra is a province located in the western part of Indonesia which has abundant natural resource potential. The area along the equator has natural resources from various fields including agriculture, plantation, mining, fishery, and tourism, small and medium industries. Dumairy (1999), Ministry of Industry and Trade, the industries in Indonesia are classified based on their current product relations, the upstream industries consist of basic chemical industries, machinery, metals and electronics industries, while downstream industries consist of various industries and small industries. Mestika (1988), in West Sumatera $80 \%$ of the people's economy are dominated by small-scale community economic enterprises, both in the agricultural, commercial and industrial sectors.

In addition to farming activities Minang people/West Sumatera successfully develop the ability to produce various types of handicrafts, ranging from various types of wicker products to wood and iron tools (Gusti, 2007). Small businesses make a substantial contribution to job creation. Small businesses are scattered throughout the countryside, including in relatively isolated areas. Many small business activities based on agriculture, home industries, and various handicraft products (Boeke, 1995). According to Yojana and Sansad handicrafts are mostly defined as items made by hand, often with the use of simple tools, and are generally artistic and/or traditional in 
nature. The Handicraft (crafts made by hands) industry uses conventional manual methods instead of advanced technology for making various items. It is an unorganized, decentralized, laborintensive cottage industry (Jadhav, 2014; Ernst and Young, 2012).

Entering the decade of the 2000s until 2017 after the Reformation, this industry re-stretch proven at this time stands 7 production houses that produce brass craftsmanship. For now, the seven production houses in Nagari Sungai Puar are constantly producing these products. In the marketing of this brass handicrafts, the impact is felt by the increase of production house and the increasing demand for handicraft products from brass in this small industrial sector that is indirect can reduce unemployment.

Many workers who work in this industry are children who cannot continue school or who drop out of school. Even many who work as craftsmen have a side job as a farmer. This is because of making brass products have long stages and processes while waiting for the next stage they can find additional income by farming. Departing from the background that has been described above, the authors are interested to examine the journey of the brass craft industry in Nagari Sungai Puar. Here the author will try to see how the process of brass casting of brass handicraft ganto product in Nagari Sungai Puar. 


\section{MATERIALS AND METHODS}

The author used qualitative research by using a descriptive approach. Descriptive concerned with process rather than simply with outcomes or product; qualitative research tends the analyze their data inductively; and meaning is the essential concern to the qualitative approach (Kristiawan, 2017). Nazir interprets qualitative method is a method in researching the status of human groups, an object, a set of conditions, a system of thought, or a class of events in the present. This descriptive method can be run by conducting a survey at the research location. This research used recycled alloy brass base material. The materials used in this research were casting furnace (smelting), sand mold, kowi, long pliers of digital thermometer, blower, gloves, clamp, microstructure observation tool and hardness testing tool.

\section{RESULTS AND DISCUSSION}

The casting process of sand molds was mold preparation, preparation and smelting of metals, casting of molten metal into molds, cleaning the castings and recycling sand molding processes. The casting product is called castings or cast objects. The weight of the castings itself is different, ranging from a few hundred grams to several tons with different compositions, and almost all metals can 
be melted and casted. The casting process, in general, can be distinguished in the process of casting and printing. In the process, the retailer does not use pressure while filling the mold cavity, while the molten metal printing process is pressed to fill the mold cavity. The different metal fills with different molds, so mold printing process is generally made from sand. In the mold casting process is usually made of sand although sometimes used plaster, clay, ceramic or other refractory materials. The first step in making a cast object is pattern preparation.

This pattern is somewhat different than its own cast object. These differences include pattern suits to offset depreciation and other additions to facilitate casting. Patterns are usually made from wax because they are relatively inexpensive and easily formed. Since the use of patterns is usually limited, patterns need not be made of durable material. In contrast, the pattern required for the production of large quantities is usually made of metal as it is more durable in use.

Metallic patterns do not change shape and do not require special care. Types of metals that are widely used for patterns are brass, copper and aluminum. There are two ways of casting by using sand molds. The division is based on the type of pattern used: 1) patterns that can be used over and over; and 2) disposable patterns. The order of discussion of the casting process is as follows 1) molding procedure; 2) pattern making; 3) sand; 4) core; 5) 
equipment (mechanical); 6) metals; and 7) casting and cleaning casting. Silica sand ( $\mathrm{SiO} 2)$, found in many places, and spread throughout the archipelago. This sand is suitable for molds because of high-temperature resistance without decomposition, low cost, durable and grain has various levels of greatness and shape. However, the reaping rate is high and has a tendency to merge into one with metal.

Firdaus (2001) is one of the ganto product craftsmen, according to Zikri who works in the printing section, the steps done to do the casting of ganto products are 1) preparing tools and materials to be used at the time of casting, after the tools and materials are prepared just starting at the making ganto or casting model; 2) after the tools and materials are prepared just start on melting brass used in the furnace melting. The method used to melt brass is using a smelting furnace, which comprises and bricks the ground of hat as a foundation and above place the drum that has been split to place the brass that has been melted. The time spent for the smelting is about 2 hours; 3) brass that cannot be melted means a lot of dirt, kindly melt again in the melting furnace in order to separate the brass with the dirt. The way of melting furnace is that the brass is burned to melt and the clean brass will melt and then flow out through the hole or funnel provided. 


\subsection{Examining Sand}

The molding sand needs to be tested periodically to determine its properties. Tests commonly applied are mechanical tests to determine the properties of sand 1) porosity of sand allows the release of gas and vapor formed in the mold; 2) the strength of the sand must have a force of cohesion, moisture content and clay, affecting the properties of the mold; 3) resistance to high temperature. Sand must withstand high temperatures without melting; 4) the size and shape of the sand granules shall be in accordance with the nature of the resulting surface. The granules should be irregularly shaped to have adequate bonding strength for casting. There are several techniques of making brass handicrafts that are adapted to the materials are recurrent casting techniques, and disposable casting techniques. Tool and technique used is cast.

When the bronze culture began to enter Indonesia, it was known as bronze processing technique, there were some craft objects from bronze materials such as bronze gendering, axes, vessels, and jewelry. The bivalve technique is also called repetitive pouring technique because it uses two keeping molds made of stone and can be used repeatedly according to need.

The inlet, addition and characterization of corrosion casting and gating systems to deliver liquid metal into the molding cavity, composed of pouring cans, descending ducts, conductors and ducts 
in which the metal flows into the molding cavity. The function of the inlet system should be well designed with the following factors 1) the metal stream should enter the mold cavity on a base or near base with minimum turbulence especially on small castings; 2) the erosion of inlet and inlet cavity walls should be suppressed by regulating liquid metal flow or by using dry sand core; 3) the incoming stream of molten metal shall be arranged, then it appears the directed solidification. Solidification should start from the mold surface to the molten metal so there is always a reserve liquid metal to cover the deficiency due to the shrinkage; 4) try to prevent foreign holes, dirt or particles from entering the cavity (Fathi Aghdam \& Mahmodi Lafvat, 2016).

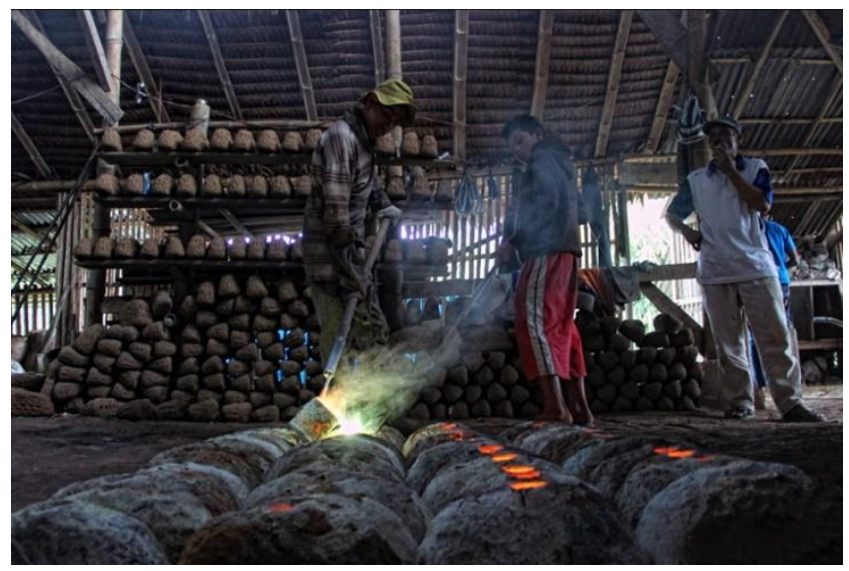

Figure 1: Pouring Brass Liquid into the Mold

The figure above looks the first casting process is done after the melting brass finished, then poured brass fluid into the mold that has 

casting mold

been provided. By using a tool in the form of pliers and spoon pour. After the brass is poured into the mold, then wait the cold approximately +15 minutes then open the ganto mold.

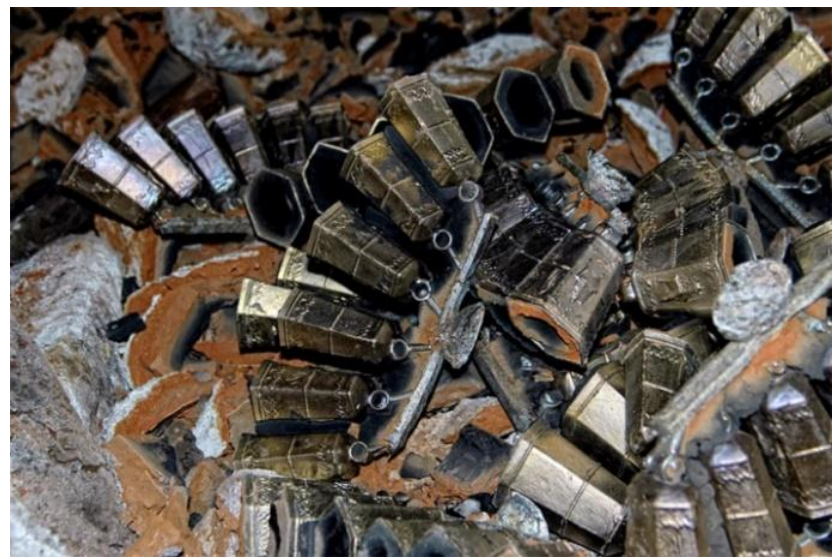

Figure 2: The Result of Ganto

The figure above is the product form Ganto according to the employees Yurdar Produk which called Sap explains how the company used to finish a craft product:

1) clean the ganto parts by using a tool in the form of lathe and a flat-shaped lathe knife. Knives used for finishing ganto are 2 kinds rough and smooth, the rough knife is used to clean the outside of ganto, after that just use a fine lathe knife. For more refined again rubbed with coarse sandpaper and fine sandpaper; 2) for finishing the top ganto by using lathe and lathe knife. Knives are used there are 2 kinds that serve to help when the latter, a rough knife is used to clean the rough outer afterward using a fine lathe knife. After the outside of 
ganto smooth then rubbed fine sandpaper, last rubbing sack of jute to shine the inside of the pot; 3) next is the outside of ganto by using lathe tool and lathe knife. The knife used 2 kinds of rough knife and fine knife. The first knife used is a rough knife and then a fine knife after a bit smooth. Then rubbed with sandpaper on the outer body of ganto and the last rubbed sack for a shiny sack.

\subsection{Products}

Products produced from apar Zikri is a form of ganto which consists of various types, this type of ganto puts its function and beauty. When viewed from the types of products produced can be categorized as a functional product. Couto the function of craft art created by man is not only aimed at decoration alone, but its main function is used for other purposes outside the arts. The above explanation then the objects produced at the center of brass handicrafts in Zikri apar including functional products 1) Ganto, 2) Carano, 3) Periuk, Print cakes and orders from consumers. Products made on Zikri apar craftsmen is ganto, this product consists of two forms ganto hexagon and ganto round shape. The shape of this ganto is related to the sound, then the ganto product made is always related to the sound, below the form of ganto produced. 


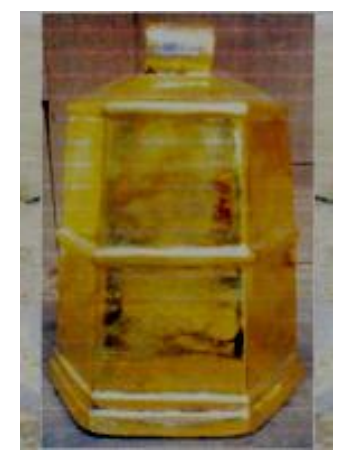

Figure 3: Form of Ganto Six Angles

The figure above looks Ganto hexagon was originally made of wood, then developed using brass material. The form of ganto hexagon itself is created based on the customary philosophy of duduak sajamba in Minangkabau adat that is composed of ninik mamak alim ulama, cadiak pandai, bundo kanduang and tuanku. In addition, the shaping of the hexagon is due to each side of the angle to produce six different tones like the tone of musical notes (Interview, Mr. Zikri, July 2017, at Puar River). Ganto hexagon by Puar River community called ganto plain, this is because there is no element of decoration on the body ganto, because for the people of Puaga River ganto is not plain, there are elements of motive in constructing or they call ganto baragi.

However, if examined this ganto is not included ganto plain, because at the bottom, middle and top there is an element of adding lines on each side of the more prominent, the line is called the value, so the line contained in ganto eliminate the impression plain on the structure ganto, ganto this measuring 10x6 cm with a height of $14 \mathrm{~cm}$. This upper ganto shrinks, which is characterized by a hollow circle 
located on the top and at the top there is a hole to engage the rope. While the inside of the hollow there is a small pendulum with round shape tied with a rope on the side of the head ganto was given a small hole where the rope pendulum entry is not easily separated. This pendulum will collide with the body of the inner ganto when shaken, resulting in sound. In ganto for souvenirs are made of brass pendants, while in ganto large size of the pendulum is made from hardwood.

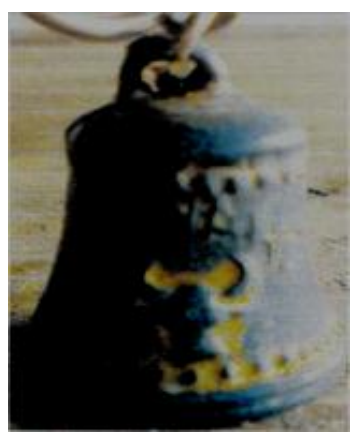

Figure 4: The Form of Circle Ganto, the Motive was Head of Buffalo

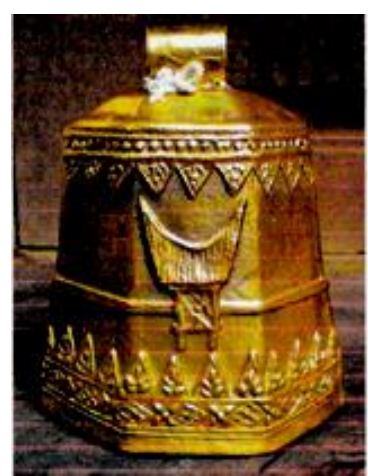

Figure 5: Ganto Buffalo 

casting mold

The figure above shows the product of ganto used as a marker on the buffalo mounted on the buffalo neck, with the size of $8.5 \times 5 \mathrm{~cm}$ height $11 \mathrm{~cm}$, the thickness was $4 \mathrm{~cm}$ while measuring $2 \times 2 \mathrm{~cm}$. At the beginning of making this ganto is without the element of decoration, because give priority to loud sound. But in line with its development, this ganto has been decorated with ornamentation on the side of his body as an element of beauty enhancer. Motifs used in the form of pitih-pitih, kaluak naku, pucuak rabuang, and rangkiang, color on ganto based on original brass color (Mardani \& Fallah, 2018).

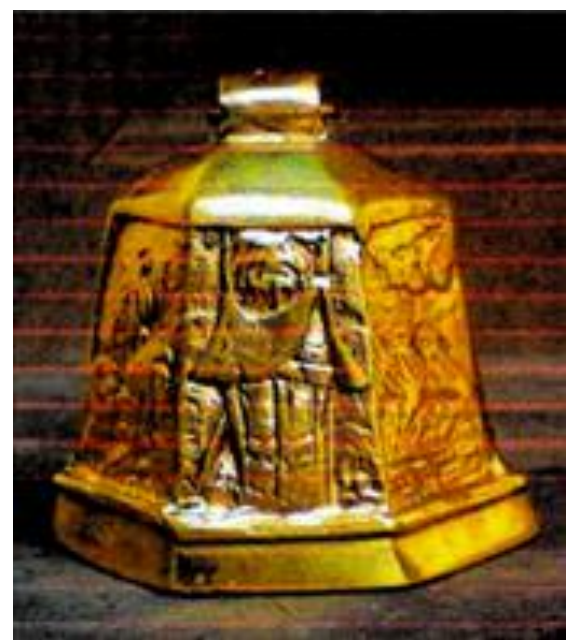

Figure 6: Ganto Goat

There are also decorated with pitiful-pitiful motives of nails. This is the motif as an addictive element of ganto. This ganto has a difference with a buffalo gland that in its size. Ganto goats have a size of $5.5 \times 3.8 \mathrm{~cm}$ with a height of $5.5 \mathrm{~cm}$, this ganto thickness is $4 \mathrm{~cm}$, while the size is $1 \times 1 \mathrm{~cm}$. 


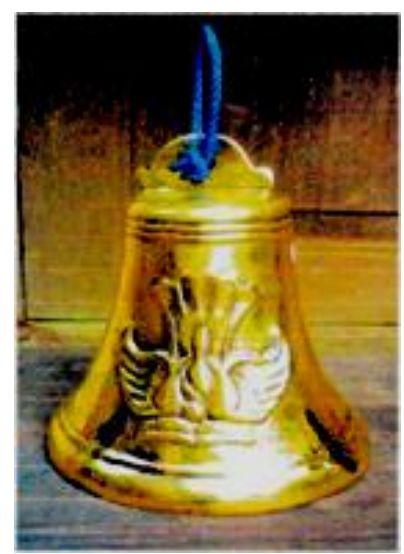

Figure 7: Ganto Bell

The figure above looks ganto bell product is the development of the previous ganto products, but this ganto is not so famous than the ganto hexagon, because the ganto round is not the main characteristic of ganto contained in Minangkabau. This product has a thickness of $3 \mathrm{~cm}$, lower diameter $14.5 \mathrm{~cm}$ in diameter, and on the top $7 \mathrm{~cm}$ in diameter, and $17 \mathrm{~cm}$ in height while on talereknya $5.5 \mathrm{x}$ $3 \mathrm{~cm}$ in the form of a semicircle which in the middle is given a hole for the rope as a carrier under the roof of the house. Ganto bells are usually found in schools, this ganto is an element of decoration on the body in the form of the symbol Tut Wuri Handayani (Vargas et al., 2019). 

casting mold

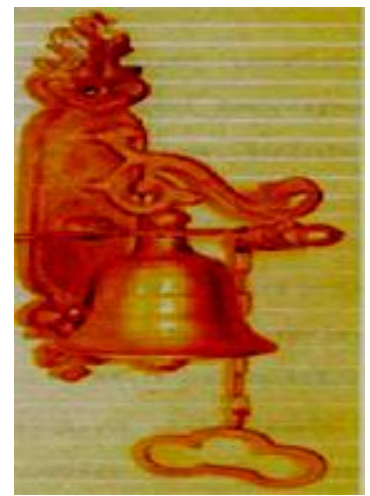

Figure 8: Ganto Doorbell

The figure above looks ganto for the doorbell but absence of decoration elements on the body, this is done because it prefers the sound, the sphere is the same as the ganto key toy, but at the head is given the handle in which there is a bolt, to look practical and simple, it is beautified the decorative elements with motif kaluak nails. There is a small hole for transport on the wall of the house with a width of 5 $\mathrm{cm}$ and $20 \mathrm{~cm}$ high. Ganto bell shaped with a diameter of $5 \mathrm{~cm}$, height $8 \mathrm{~cm}$, and thickness was $3 \mathrm{~mm}$.

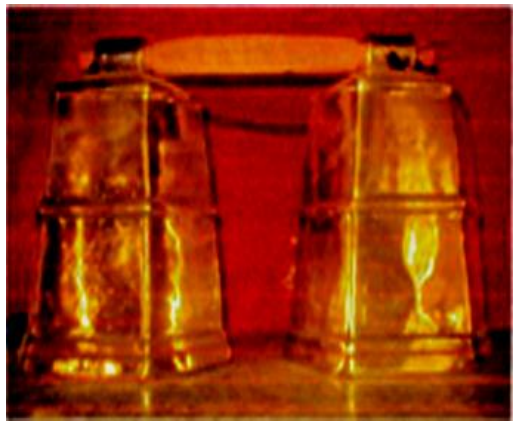

Figure 9: The Form of Previous Ganto 
The figure above looks that the shape of this ganto is basically without motive because in this ganto there are only line elements that decorate on each side of the body. This ganto has large size $10 \times 6 \mathrm{~cm}$ with height $14 \mathrm{~cm}$, because this ganto not as ganto souvenir, but used for markers and entertainers for the coachman in the cart. This Ganto is in the form of hexagon is not the same side, which increasingly upwards the smaller. In the pendulum does not use brass, but using materials from hardwood, the purpose to offset the body weight of ganto, then given a light pendulum so that the resulting sound is more echoed, at the top, to serve as a place of transport ganto on wood will be on the side of the lower roof of the cart, will always sway while the cart is running. Usually, one cart coupled with wood on the upper side.

\section{CONCLUSION}

Sand casting process proved able to work material product ganto. It is a famous industry in Nagari Puar River. The existence of this metal processing industry already existed in the 1800s and still continues today. The brass handicraft industry is a business developed and passed down from generation to generation. The brass handicraft industry has undergone a change from a period of goodness in terms of the type of product produced and the focus of production applied by every craftsman. In the early development of brass handicrafts existing in Nagari Sungai Puar is in making ganto. Ganto is one of the objects

of brass casting that continues to produce the brass handicrafts in Jorong Kapalo Koto, especially the production center of Zikri ganto. 
Ganto experienced the development of the form, especially the size and function. The functioned object was as markers in farm animals, now become as souvenir items.

\section{REFERENCES}

BOEKE, J. 1995. Capitalism in Asia. Jakarta: Sinar Harapan. Indonesia.

DUMAIRY, A. 1999. Indonesia Economy. Jakarta: Erlangga. Indonesia.

ERNST, A., \& YOUNG, L. 2012. Competitive study on Handicrafts Sector in China. Retrieved from website of Exports Council of India. India.

FIRDAUS, S. 2001. Design of Squeeze Casting Process for Flens River Motor Development. Thesis Universitas Indonesia. Indonesia.

GUSTI, A. 2007. World Maritime Sumatera Beach. Yogyakarta: Ombak. Indonesia.

JADHAV, M. 2014. Indian Handicrafts: Growing or Depleting? IOSR Journal of Business and Management (IOSR-JBM) eISSN: 2278-487X, p-ISSN: 2319-7668. pp. 07-13. Egypt.

KRISTIAWAN, M. 2017. The Characteristics of the Full Day School Based Elementary School. Transylvanian Review. Vol. 1, $\mathrm{N}^{\mathrm{o}}$ 1. Romania.

MESTIKA, Z. 1998. West Sumatera in Historical Stage 1945-1995. Jakarta: Sinar Harapan. Indonesia. 
FATHI AGHDAM, P., \& MAHMODI LAFVAT, M. (2016). An Empirical Study: Investigating the Relationship between Threats and Risk of Competitors on Business Effectiveness in Distributor Companies of Detergent Material. UCT Journal of Management and Accounting Studies, 4(1), 29-34.

VARGAS, F., BENINCASA, T., CIAN, G., \& MARTIGNON, L. (2019). Fostering Probabilistic Reasoning Away from Fallacies: Natural Information Formats and Interaction between School Levels. International Electronic Journal of Mathematics Education, $14(2)$, 303-330. https://doi.org/10.29333/iejme/5716.

MARDANI, M., \& FALLAH, R. (2018). Comparison of Financial Leverage Ratio before and after the Use of Off-Balance Sheet Financing in Firms Listed in the Tehran Stock Exchange. Dutch Journal of Finance and Management, 2(2), 53. https://doi.org/10.29333/djfm/5829. 



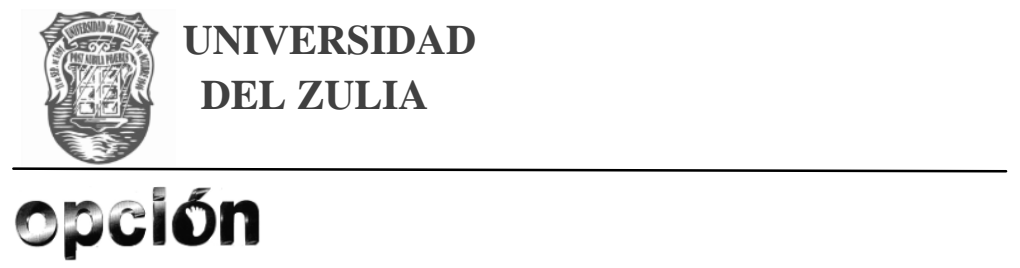

Revista de Ciencias Humanas y Sociales

Año 35, Especial No 21, (2019)

Esta revista fue editada en formato digital por el personal de la Oficina de Publicaciones Científicas de la Facultad Experimental de Ciencias, Universidad del Zulia.

Maracaibo - Venezuela

www.luz.edu.ve

www.serbi.luz.edu.ve

produccioncientifica.luz.edu.ve 